\title{
PHYSIOLOGICAL IMPACTS OF USING CLOVE POWDER AS FISH ANESTHETIC ON YOUNG COMMON CARP (CYPRINUS CARPIO L.) UNDER DIFFERENT LEVELS OF TEMPERATURES
}

\author{
Nasreen M. Abdulrahman ${ }^{1 *}$, Bakhan R. Hassan ${ }^{2}$ and Nadir A. Salman ${ }^{3}$ \\ ${ }^{1,2}$ Department of Animal Science, College of Agricultural Sciences, University of Sulaimani, Iraq. \\ ${ }^{3}$ College of Agriculture, University of Basrah, Iraq. \\ *Corresponding author's E-mail: nasreen.abdulrahman@univsul.edu.iq
}

\begin{abstract}
The anesthetic efficacies of natural anesthetic (clove) in forms of powder were evaluated on young common carp (Cyprinus carpio L.) with the mean weight of $60 \pm 10 \mathrm{~g}$ for handling and health management experiments. These works were conducted in the laboratory of fish research in the Department of Animal Science, Collage of Agricultural Sciences at University of Sulaimani. Safety concentrations of anesthetics type and concentration were assessed by using form of clove (powder); each with three replicates within each replicate five fish used for measuring induction times to anesthesia. The induction time of $C$. carpio which decrease with increasing concentrations of clove powder, the induction time was less than three minutes for a dose of $400 \mathrm{mg} / \mathrm{L}$, with significant different $(P<0.05)$ from the other dosages. As the concentrations of clove powder increased the ventilation rate in stage I, II and III of anesthesia and recovery increased significantly $(P<0.05)$ compared to the control. There were no mortalities at any of the temperatures or concentrations, 24 hours after recovery. In stage I, II and III of recovery, all three concentrations of clove powder with normal temperature degree showed lower ventilation rate compared to other groups. The lowest cortisol level of anesthesia was found in the low temperature degree with $300 \mathrm{mg} / \mathrm{L}$ of clove powder. The lowest and the highest sugar levels were found in low temperature degree with 300 and $400 \mathrm{mg} / \mathrm{L}$ of clove powder, respectively. Clove powder of $200 \mathrm{mg} / \mathrm{L}$ with normal temperature degree showed the lowest level of red blood cell.
\end{abstract}

Keywords: Anesthesia, Common carp, Clove powder, RBC, plasma cortisol, sugar level, WBC.

\section{INTRODUCTION}

Practices that require fish handling are a common source of stress in aquaculture operation, research activities and monitoring projects (Kakoolaki et al., 2010), to solve this problem, fish handlers have employed the use of anesthetics, added to water, to immobilize fish, reduce stress levels, and prevent mortality. This allows animals to undergo intervention, surgery and other procedures without the distress and pain. The use of anesthetics facilitates work with fish at the research level and is required for invasive studies such as surgical preparations for physiological investigations, where the fish must be held immobile for extended periods of time (Gholipourkanani et al., 2011). However, the use of fish anesthesia in field studies has been constrained by regulations governing potential human consumption of fish after anesthesia (Trushenski $\boldsymbol{e t}$ al., 2013).

\section{Original Article: $\underline{18.62720}$ \\ Received: 18 April, 2018 \\ Accepted: 22 June, 2018 \\ Published: 12 July, 2018}

DOI:https://dx.doi.org/10.21608/javs.20

This is an open access article under the term of the Creative Commons Attribution 4.0 (CC-BY) International License . To view a copy of this license, http://creativecommons.org/licenses/by/4.0/

J. Appl. Vet. Sci., 3(1): 1-11.
The progress of induction, and the depth of anesthesia, is generally divided into different stages and planes. Common parameters that are evaluated in order to determine these stages and planes during anesthesia of animals include behaviour, activity, eye signs, muscle tone, reflexes, respiratory rate, heart rate, and blood pressure. As several of these parameters are difficult to assess in fish it may be difficult to distinguish one stage or plane from the other, especially in situations where induction is fast. In fish stages and planes are therefore usually described by changes in swimming activity, balance, respiratory frequency as well as reactions to external stimuli (Zahl, 2011). The anesthesia-induction stages suggested by Marking and Meyer (1985) (Table 1), and stages of anesthesia and recovery by Iwama $\boldsymbol{e t}$ al. (1989) (Table 2) were adopted in this experiment. 


\section{Physiological Impacts Of Using Clove Powder As Fish Anesthetic ......}

Table 1: Anesthesia-induction stages from Marking and Meyer (1985).

\begin{tabular}{|c|r|c|}
\hline Stage & Condition & Behavior/Response \\
\hline I & Sedation & Motion and breathing reduced \\
\hline II & Anesthesia & $\begin{array}{r}\text { Partial loss of equilibrium } \\
\text { Reactive to touch stimuli }\end{array}$ \\
\hline III & Surgical & $\begin{array}{r}\text { Total loss of equilibrium } \\
\text { anesthesia }\end{array}$ \\
\hline IV & Death reaction to touch stimuli \\
\hline & $\begin{array}{c}\text { Breathing and heart beat stop } \\
\text { Overdose - eventual death }\end{array}$ \\
\hline
\end{tabular}

Table 2: Anesthesia and recovery from Iwama $\boldsymbol{e t}$ al. (1989).

\begin{tabular}{|c|c|}
\hline $\begin{array}{r}\text { Stages of } \\
\text { Anesthesi }\end{array}$ & Description \\
\hline I & Loss of equilibrium \\
\hline II & $\begin{array}{c}\text { Loss of gross body movements but } \\
\text { with continued opercula movements }\end{array}$ \\
\hline III & $\begin{array}{c}\text { As in Stage II with cessation of } \\
\text { opercula movements }\end{array}$ \\
\hline $\begin{array}{c}\text { Stages of } \\
\text { Recovery }\end{array}$ & Description \\
\hline I & $\begin{array}{c}\text { Body immobilized but opercula } \\
\text { movements just starting }\end{array}$ \\
\hline II & $\begin{array}{c}\text { Regular opercula movements and gross } \\
\text { body movements beginning }\end{array}$ \\
\hline III & $\begin{array}{c}\text { Equilibrium regained and preanesthetic } \\
\text { appearance }\end{array}$ \\
\hline
\end{tabular}

Anesthetics may be local or general depending on their purpose and application, also, method and administration for each anesthetics is fairly well defined (Velíšek et al., 2005), but the choice of anesthetic depends on a number of factors. For example, if the maintenance of gill ventilation during an experimental procedure is desirable, then ketamine hydrochloride would be one possible anesthetic. In minimizing transportation stress, a light sedation brought about by low concentrations of an anesthetic such as TMS buffered with sodium bicarbonate. Anesthetics such as MS-222, clove oil, quinaldine sulphate, and metomidate are popularly used during production procedures in fish hatcheries process (Holloway et al., 2004; Akinrotimi et al., 2013). The ideal level of sedation for fish transport is referred to as deep sedation and includes loss of reactivity to external stimuli, decrease in metabolic rate, but maintenance of equilibrium. If fish are too heavily sedated, lose equilibrium, and cease swimming, they may die from suffocation if they all settle to the bottom, or experience mechanical injury from hitting the tank walls (Wagner et al., 2003).

There are little studies about fish anesthesia in Iraq. Al-Jashami et al. (2002), used clove powder (Eugenia caryophyllata) as a new anesthetic for common carp C. carpio. Fry, fingerling and mature fish had undergone different concentrations of the anesthetic ranged $120-230 \mathrm{mg} / \mathrm{L}$. They found that $190 \mathrm{mg} / \mathrm{L}$ of clove solution considered as effective and suitable anesthetic for common carp.

According to all that the objectives of the project were evaluate the anesthetic effects and safe use of natural agent such as clove powder in health treatments research. Determine the stress response of common carp (C. carpio L.) to natural anesthesia. And provide information about the management of Anesthesia for practices with the local fish species regarded with temperature.

\section{MATERIALS AND METHODS}

Common carp fish were chosen to evaluate the efficacy of anesthetic in the powder form approaches in this study. Common carp were chosen for the study due to their high abundance in Kurdistan, marked tolerance to culture conditions, and the first species that reared in Kurdistan and Iraq. Also have a good survival rates and a highly tolerant for aquarium conditions, making them prime species for the experimental design of this study. All fish used in this study were held in aquarium tanks located at the fish lab in Animal Production Department, College of Agricultural Sciences, University of Sulaimani.

\section{Experimental procedure}

Aquaria was equipped with aeration stone consisted of large glass tanks $(100 \mathrm{~cm} \times 50 \mathrm{~cm} \times 60 \mathrm{~cm})$ containing approximately 150 liters of water, Studied fish were acclimated for a minimum of two weeks prior to the outset of experiments, ensuring that they had sufficiently recovered from possible capture-related or transport stress. The fish were unfed for 24 hours prior to the experiments (Brown, 2011). Tanks were cleaned by siphon method to remove feces and remained nonconsumed feed, after cleaning all tanks were discharged with same amount, physical and chemical property of water. 
Aquaria water quality parameters were monitored throughout changing of the water biweekly duration of the study. Fish were held for a period of two months following the experiments to assess long-term mortality. In order to reduce observer variability, the same observer monitored progression through the stages of anesthesia and recovery throughout all of the experiments. Each fish in each replicate treated alone. Each anesthetic bath was individually prepared before use (anesthetic and recovery aquaria was 30-L glass tank), water was replaced between each fish treated, and the tank was rinsed before preparation of the next concentration. Each fish was individually monitored from the time of immersion in the anesthetic bath to determine the time required to reach each stage of anesthesia up to stage three, which is characterized by loss of sensation, total loss of swimming motion, and total loss of equilibrium (Ross and Ross, 2008).

Induction and recovery times were measured with a video recorder to the nearest second. Following the induction into stage $\amalg$ each fish was weighed and transferred to a recovery aquaria that had been filled with aerated freshwater at the same time of preparation the anesthetic baths. In the recovery tub the fish were monitored continuously to determine time to full equilibrium. Recovered fish were promptly returned to their holding system and monitored for survival at 24 and 72 hours post-experiment (Iwama et al., 1989). Several concentrations of anesthetic agents were tested. By using a video recorder, time was recorded for:

a)Stage I anesthesia: partial loss of equilibrium, some body movements and reduced reaction to external stimuli.

b) Stage II anesthesia total loss of equilibrium, no body movements, no reaction to external stimuli.

c)Stage III anesthesia as in stage II with decrease in opercula rat.

d) Recovery time Recovery of equilibrium, body movements and response to external stimuli.

The maximum exposure time to the anesthetic agent was 10 minute. If no anesthetic effect was observed during this $10 \mathrm{~min}$, the concentration of anesthetic was considered insufficient (Ross and Ross, 2008). Individual fish weight $(\mathrm{g})$ were measured in $<1$ minuet as soon as stage III anesthesia was reached and before fish were moved to the recovery tank (containing clean fresh aerated water).

\section{Water quality}

Some essential water quality parameters were measured during the experimental period. These include water dissolved oxygen $(\mathrm{mg} / \mathrm{l})$ using $\mathrm{O}_{2}$-meter (OAKTON Singapore), water temperature ${ }^{\circ} \mathrm{C}$ using thermometer ranging between zero to $100{ }^{\circ} \mathrm{C}$, water $\mathrm{pH}$ using a $\mathrm{pH}$ meter (Germane), water hardness using Hardness Test (KIT) USA, water total dissolved solids using TDS-Meter (European). Water quality parameters monitored are listed in Table (3). The current results were favorable for the growth of the fish common carp (Abu-Elhini et al., 2013).

Table 3: Water Quality parameters in the experimental tanks

\begin{tabular}{|l|c|}
\hline \multicolumn{1}{|c|}{ Parameters } & Values \\
\hline Temperature $\left({ }^{\circ} \mathrm{C}\right)$ & $28 \pm 1$ \\
\hline Dissolved Oxygen (mg/L) & $4 \pm 1$ \\
\hline Hardness (ppm) & $330 \pm 10$ \\
\hline $\mathrm{pH}$ & $7 \pm 0.5$ \\
\hline TDS $(\mathrm{ppm})$ & $230 \pm 10$ \\
\hline
\end{tabular}

\section{Blood parameters}

The blood samples from each fish of the different groups were collected by suction of the caudal peduncle. Whole blood samples were collected in heparinized vials for determination of some blood indices which were determined by using the hematology analyzer BC-2800 is a compact, fully automatic hematology analyzer USA origin for complete blood count (CBC) test. Blood plasma was being separated from the fish whole blood by centrifugation for 3-5 minutes at $4500 \mathrm{~g}$. Plasma samples were used for the purpose of conducting experimental test of blood sugar (Sugar/mmol/L) by using a hematological analyzing device type ACCENT 200 Poland's origin. Also blood plasma used for testing cortisol hormone (Cortisol/nmol/L) by using COBAS C 111 German's origin device.

\section{Experimental design}

In this experiment the anesthetics effect of clove powder was investigated at three concentrations and control, for each concentration three replicate were used, anesthetics were dosed as followed:

Anesthetic: 200, 300 and $400 \mathrm{mg} / \mathrm{L}$ of clove powder.

Each replicate aquarium was stocked with five fish. The aquaria (replicates) were randomly allocated to minimize the differences among treatments. The continuous water flow discharged non-consumed feed and feces particles from the aquaria. The clove powder used in the experiment was obtained from local markets in Sulaimani that naturally used for other human purposes.

Trials of clove powder as alternative anesthesia used to study the effect of water temperature (normal, warm and cold conditions) on fish anesthesia. The temperature in the observation aquaria was kept constant by using worm, cool water and ice for 
controlling each water temperature level, and the temperature was measured during the test.

Clove powder as an alternative anesthesia in 200, 300 and $400 \mathrm{mg} / \mathrm{L}$ with temperature represented in nine treatments.

* High Temperature $\left(33 \pm 1^{\circ} \mathrm{C}\right)$

* Normal Temperature $\left(27 \pm 1{ }^{\circ} \mathrm{C}\right)$

* Low Temperature $\left(9 \pm 1{ }^{\circ} \mathrm{C}\right)$

\section{Statistical analysis}

Statistical analysis results are shown as mean values in tables. The statistical calculations of the results were completed using XLSTAT. Pro. one way (ANOVA). Different letters were given to different treatments. The experiment was conducted using the (Factorial CRD) procedure of XLSTAT. Pro. two way (ANOVA). Duncan's test's was used to compare between means of the treated groups according to $P<0.05$ significance. The hypothesis test for interaction was carried out first. The main effects were tested when the effect of interaction was not significant. While in case of significant effect for the interaction the test was not performance for the main effects (Kaps and Lamberson, 2004).

\section{RESULTS}

Table 4: Effects of three levels of clove powder $(\mathrm{mg} / \mathrm{L})$ with three temperatures levels on anesthesia time (second) in common carp for the three stages of anesthesia (Mean \pm SD).

\begin{tabular}{|c|c|c|c|c|c|c|c|c|c|}
\hline \multirow{3}{*}{ Doses } & \multicolumn{9}{|c|}{ Anesthesia Time (sec.) } \\
\hline & \multicolumn{3}{|c|}{ Stage I } & \multicolumn{3}{|c|}{ Stage II } & \multicolumn{3}{|c|}{ Stage III } \\
\hline & Low & Normal & High & Low & Normal & High & Low & Normal & High \\
\hline $200 \mathrm{mg} / \mathrm{L}$ & $186.5 \pm 0.3$ & $106 \pm 0.18^{c c}$ & $457.5 \pm 0.11$ & $382 \pm 0.05^{b}$ & $453 \pm 0.03^{\mathrm{a}}$ & $490 \pm 0.15^{\mathrm{a}}$ & $373.3 \pm 0.15^{\mathrm{b}}$ & $514.6 \pm 0.01^{\mathrm{a}}$ & $540 \pm 0.15^{\mathrm{a}}$ \\
\hline $300 \mathrm{mg} / \mathrm{L}$ & $76.5 \pm 0.25$ & $62.5 \pm 0.04^{\mathrm{d}}$ & $109.5 \pm 0.01$ & $115 \pm 0.02^{\mathrm{c}}$ & $142 \pm 0.08^{\mathrm{c}}$ & $135.5 \pm 0.06$ & $202.33 \pm 0.34^{\mathrm{c}}$ & $375.6 \pm 0.24^{b}$ & $165.6 \pm 0.2^{\mathrm{c}}$ \\
\hline $400 \mathrm{mg} / \mathrm{L}$ & $141.5 \pm 0.1$ & $54 \pm 0.03^{\mathrm{d}}$ & $48.5 \pm 0.05^{\mathrm{d}}$ & $147.5 \pm 0.12^{\mathrm{c}}$ & $153.5 \pm 0.02$ & $67 \pm 0.06^{\mathrm{d}}$ & $235.66 \pm 0.37^{\mathrm{c}}$ & $233.6 \pm 0.08^{c}$ & $54.6 \pm 0.08^{c}$ \\
\hline
\end{tabular}

Mean values with different superscripts within a same stage are different significantly $(P<0.05)$

Table 5: Effects of three levels of clove powder $(\mathrm{mg} / \mathrm{L})$ with three temperatures levels on anesthesia time (second) in common carp in the three stages of recovery (Mean \pm SD).

\begin{tabular}{|c|c|c|c|c|c|c|c|c|c|}
\hline & \multicolumn{9}{|c|}{ Recovery Time (sec.) } \\
\hline & \multicolumn{3}{|c|}{ Stage I } & \multicolumn{3}{|c|}{ Stage II } & \multicolumn{3}{|c|}{ Stage III } \\
\hline & Low & Normal & High & Low & Normal & High & Low & Normal & High \\
\hline $200 \mathrm{mg} / \mathrm{L}$ & $45 \pm 0.53^{\mathrm{bc}}$ & $41 \pm 0.03^{\mathrm{c}}$ & $80 \pm 0.23^{\mathrm{abc}}$ & $73.5 \pm 0.16^{c}$ & $71 \pm 0.06^{\mathrm{c}}$ & $107.5 \pm 0.36^{\mathrm{ab}}$ & $234 \pm 0.32^{\mathrm{ab}}$ & $337.5 \pm 0.01^{\mathrm{a}}$ & $207 \pm 0.42^{\mathrm{b}}$ \\
\hline $300 \mathrm{mg} / \mathrm{L}$ & $86 \pm 0.32^{\mathrm{abc}}$ & $44 \pm 0.12^{\mathrm{bc}}$ & $70.5 \pm 0.05^{\mathrm{bc}}$ & $114 \pm 0.07^{\mathrm{ab}}$ & $86.5 \pm 0.15^{\mathrm{bc}}$ & $109.5 \pm 0.12^{\mathrm{ab}}$ & $198.5 \pm 0.29$ & $240.5 \pm 0.02^{\mathrm{ab}}$ & $88.5 \pm 0.25^{b}$ \\
\hline $400 \mathrm{mg} / \mathrm{L}$ & $126.5 \pm 0.4^{\mathrm{ab}}$ & $79 \pm 0.14^{\mathrm{abc}}$ & $155 \pm 0.55^{\mathrm{a}}$ & $153.5 \pm 0.29$ & $106 \pm 0.01^{\mathrm{abc}}$ & $147.5 \pm 0.33^{\mathrm{ab}}$ & $289 \pm 0.01^{\mathrm{ab}}$ & $265 \pm 0.06^{\mathrm{ab}}$ & $57.5 \pm 0.07^{\mathrm{ab}}$ \\
\hline
\end{tabular}

Mean values with different superscripts within a same stage are different significantly $(P<0.05)$ 
Table 6: Effects of three levels of clove powder $(\mathrm{mg} / \mathrm{L})$ with three temperatures levels on anesthesia ventilation rate $/ 15 \mathrm{sec}$. in common carp at the three stages of anesthesia (Mean $\pm \mathrm{SD}$ ).

\begin{tabular}{|c|c|c|c|c|c|c|c|c|c|}
\hline \multirow{3}{*}{ Doses } & \multicolumn{9}{|c|}{$\begin{array}{c}\text { Anesthesia ventilation rate/ Temperature } \\
\text { Ventilation rate } / 15 \mathrm{sec} \text {. }\end{array}$} \\
\hline & \multicolumn{3}{|c|}{ Stage I } & \multicolumn{3}{|c|}{ Stage II } & \multicolumn{3}{|c|}{ Stage III } \\
\hline & Low & Normal & High & Low & Normal & High & Low & Normal & High \\
\hline $\begin{array}{c}200 \\
\mathrm{mg} / \mathrm{L}\end{array}$ & $\begin{array}{l}20.66 \\
\pm 0.03^{\mathrm{d}}\end{array}$ & $\begin{array}{l}25.33 \\
\pm 0.02^{\mathrm{b}}\end{array}$ & $\begin{array}{l}25.33 \\
\pm 0.12^{\mathrm{b}}\end{array}$ & $\begin{array}{l}18.66 \\
\pm 0.03^{\text {de }}\end{array}$ & $\begin{array}{l}17.33 \\
\pm 0.13^{\mathrm{e}}\end{array}$ & $\begin{array}{l}23.66 \\
\pm 0.04^{b}\end{array}$ & $\begin{array}{l}18.33 \\
\pm 0.03^{\mathrm{c}}\end{array}$ & $\begin{array}{l}14.33 \\
\pm 0.04^{\mathrm{d}}\end{array}$ & $\begin{array}{l}22.33 \\
\pm 0.05^{\mathrm{b}}\end{array}$ \\
\hline $\begin{array}{c}300 \\
\mathrm{mg} / \mathrm{L}\end{array}$ & $\begin{array}{c}22.66 \\
\pm 0.02^{\mathrm{cd}}\end{array}$ & $\begin{array}{c}24.33 \\
\pm 0.02^{\mathrm{bc}}\end{array}$ & $\begin{array}{c}29 \\
\pm 0.03^{\mathrm{a}}\end{array}$ & $\begin{array}{c}20.33 \\
\pm 0.02^{\mathrm{cd}}\end{array}$ & $\begin{array}{c}18.66 \\
\pm 0.06^{\text {de }}\end{array}$ & $\begin{array}{c}27.66 \\
\pm 0.02^{\mathrm{a}}\end{array}$ & $\begin{array}{c}18.33 \\
\pm 0.03^{c}\end{array}$ & $\begin{array}{c}14.33 \\
\pm 0.04^{\mathrm{d}}\end{array}$ & $\begin{array}{c}26.66 \\
\pm 0.05^{\mathrm{a}}\end{array}$ \\
\hline $\begin{array}{c}400 \\
\mathrm{mg} / \mathrm{L}\end{array}$ & $\begin{array}{c}24 \\
\pm 0.04^{\mathrm{bc}}\end{array}$ & $\begin{array}{c}26.33 \\
\pm 0.02^{\mathrm{b}}\end{array}$ & $\begin{array}{c}29.33 \\
\pm 0.02^{\mathrm{a}}\end{array}$ & $\begin{array}{c}21 \\
\pm 0.14^{\mathrm{cd}}\end{array}$ & $\begin{array}{c}22.33 \\
\pm 0.02^{\mathrm{bc}}\end{array}$ & $\begin{array}{c}28.66 \\
\pm 0.02^{\mathrm{a}}\end{array}$ & $\begin{array}{l}19.33 \\
\pm 0.2^{\mathrm{bc}}\end{array}$ & $\begin{array}{c}18.33 \\
\pm 0.12^{\mathrm{c}}\end{array}$ & $\begin{array}{c}20.33 \\
\pm 0.02^{\mathrm{bc}}\end{array}$ \\
\hline
\end{tabular}

Mean values with different superscripts within the same groups are different significantly $(P<0.05)$

Table 7: Effects of three levels of clove powder $(\mathrm{mg} / \mathrm{L})$ with three temperatures levels on recovery ventilation rate $/ 15 \mathrm{sec}$. in common carp at the three stages of recovery (Mean $\pm \mathrm{SD}$ ).

\begin{tabular}{|c|c|c|c|c|c|c|c|c|c|}
\hline & \multicolumn{9}{|c|}{$\begin{array}{l}\text { Recovery ventilation rate/ Temperature } \\
\text { Ventilation rate / } 15 \mathrm{sec} .\end{array}$} \\
\hline & \multicolumn{3}{|c|}{ Stage I } & \multicolumn{3}{|c|}{ Stage II } & \multicolumn{3}{|c|}{ Stage III } \\
\hline & Low & Normal & High & Low & Normal & High & Low & Normal & High \\
\hline $\begin{array}{r}200 \\
\mathrm{mg} / \mathrm{L}\end{array}$ & $\begin{array}{c}25 \\
\pm 0.11^{\mathrm{ab}}\end{array}$ & $\begin{array}{c}14.5 \\
\pm 0.04^{\mathrm{c}}\end{array}$ & $\begin{array}{c}24 \\
\pm 0.06^{\mathrm{b}}\end{array}$ & $\begin{array}{c}25 \\
\pm 0.05^{\mathrm{a}}\end{array}$ & $\begin{array}{c}14.5 \\
\pm 0.04^{\mathrm{b}}\end{array}$ & $\begin{array}{c}23 \\
\pm 0.01^{\mathrm{a}}\end{array}$ & $\begin{array}{c}22 \\
\pm 0.06^{\mathrm{ab}}\end{array}$ & $\begin{array}{c}18 \\
\pm 0.08^{\mathrm{ab}} \\
\end{array}$ & $\begin{array}{c}22 \\
\pm 0.12^{\mathrm{ab}}\end{array}$ \\
\hline $\begin{array}{r}300 \\
\mathrm{mg} / \mathrm{L}\end{array}$ & $\begin{array}{c}25.5 \\
\pm 0.08^{\mathrm{ab}}\end{array}$ & $\begin{array}{c}14.5 \\
\pm 0.05^{\mathrm{c}}\end{array}$ & $\begin{array}{c}27.5 \\
\pm 0.02^{\mathrm{a}}\end{array}$ & $\begin{array}{c}23.5 \\
\pm 0.21^{\mathrm{a}}\end{array}$ & $\begin{array}{c}14 \\
\pm 0.01^{\mathrm{b}}\end{array}$ & $\begin{array}{c}25.5 \\
\pm 0.02^{\mathrm{a}}\end{array}$ & $\begin{array}{c}22.5 \\
\pm 0.15^{\mathrm{b}}\end{array}$ & $\begin{array}{c}16.5 \\
\pm 0.04^{\mathrm{b}}\end{array}$ & $\begin{array}{c}21.5 \\
\pm 0.03^{\mathrm{ab}}\end{array}$ \\
\hline $\begin{array}{r}400 \\
\mathrm{mg} / \mathrm{L}\end{array}$ & $\begin{array}{c}24 \\
\pm 0.01^{\mathrm{b}}\end{array}$ & $\begin{array}{c}24 \\
\pm 0.01^{\mathrm{b}}\end{array}$ & $\begin{array}{c}23 \\
\pm 0.01^{\mathrm{b}}\end{array}$ & $\begin{array}{c}24 \\
\pm 0.17^{\mathrm{a}}\end{array}$ & $\begin{array}{c}24 \\
\pm 0.05^{\mathrm{a}}\end{array}$ & $\begin{array}{c}22.5 \\
\pm 0.03^{\mathrm{a}}\end{array}$ & $\begin{array}{c}21.5 \\
\pm 0.23^{\mathrm{ab}}\end{array}$ & $\begin{array}{c}20.5 \\
\pm 0.03^{\mathrm{ab}}\end{array}$ & $\begin{array}{c}19.5 \\
\pm 0.04^{\mathrm{ab}}\end{array}$ \\
\hline
\end{tabular}

Mean values with different superscripts within the same groups are different significantly $(P<0.05)$

Table 8: Effects of three levels of clove powder with three temperatures levels on red blood cells level in common carp for anesthesia and recovery (Mean $\pm \mathrm{SD}$ ).

\begin{tabular}{|r|r|r|r|r|r|c|}
\hline \multirow{2}{*}{ Group } & \multicolumn{5}{|c|}{ RBC Counts $\left(10^{12}\right.$ cells/L } \\
\cline { 2 - 7 } & \multicolumn{3}{|c|}{ Anesthesia } & \multicolumn{3}{c|}{ Recovery } \\
\cline { 2 - 7 } Temp. & Low & Normal & High & Low & Normal & High \\
\cline { 2 - 7 } & $1.24 \pm 0.8^{\mathrm{c}}$ & $0.84 \pm 0.1^{\mathrm{f}}$ & $0.91 \pm 0.11^{\mathrm{e}}$ & $1.02 \pm 0.1^{\mathrm{d}}$ & $1.15 \pm 0.9^{\mathrm{c}}$ & $0.96 \pm 0.1^{\mathrm{e}}$ \\
\hline $200 \mathrm{mg} / \mathrm{L}$ & $1.45 \pm 0.7^{\mathrm{a}}$ & $1.43 \pm 0.7^{\mathrm{a}}$ & $1.32 \pm 0.8^{\mathrm{b}}$ & $1.15 \pm 0.9^{\mathrm{c}}$ & $1.08 \pm 0.9^{\mathrm{d}}$ & $1.05 \pm 0.1^{\mathrm{d}}$ \\
\hline $300 \mathrm{mg} / \mathrm{L}$ & $0.86 \pm 0.12^{\mathrm{ef}}$ & $1.3 \pm 0.7^{\mathrm{b}}$ & $1.03 \pm 0.01^{\mathrm{d}}$ & $1.21 \pm 0.8^{\mathrm{b}}$ & $0.84 \pm 0.12^{\mathrm{f}}$ & $1.38 \pm 0.7^{\mathrm{a}}$ \\
\hline $400 \mathrm{mg} / \mathrm{L}$ & & & & & & \\
\hline
\end{tabular}

Mean values with different superscripts within the same groups are different significantly $(P<0.05)$ 
Nasreen M. Abdulrahman, et al.

Table 9: Effects of three levels of clove powder with three temperatures levels on white blood cells level in common carp for anesthesia and recovery (Mean \pm SD).

\begin{tabular}{|c|c|c|c|c|c|c|}
\hline \multirow{2}{*}{$\begin{array}{c}\text { Groups } \\
\text { Temp. }\end{array}$} & \multicolumn{5}{|c|}{ Anesthesia } & \multicolumn{3}{c|}{ Recovery } \\
\cline { 2 - 7 } & Low & Normal & High & Low & Normal & High \\
\cline { 2 - 7 } & $187.2 \pm 5.8^{\mathrm{c}}$ & $183.9 \pm 7.1^{\mathrm{e}}$ & $165.2 \pm 8.11^{\mathrm{h}}$ & $192.8 \pm 10.1^{\mathrm{b}}$ & $171.8 \pm 11.1^{\mathrm{f}}$ & $153 \pm 6.1^{\mathrm{g}}$ \\
\hline $200 \mathrm{mg} / \mathrm{L}$ & $199.4 \pm 5.77^{\mathrm{a}}$ & $184.5 \pm 4.7^{\mathrm{e}}$ & $186 \pm 5^{\mathrm{d}}$ & $149.1 \pm 5.1^{\mathrm{h}}$ & $200.3 \pm 1.7^{\mathrm{a}}$ & $149.4 \pm 7.1^{\mathrm{h}}$ \\
\hline $300 \mathrm{mg} / \mathrm{L}$ & $177.7 \pm 8.2^{\mathrm{f}}$ & $193.2 \pm 6.1^{\mathrm{b}}$ & $176 \pm 6.1^{\mathrm{g}}$ & $175.9 \pm 8.5^{\mathrm{d}}$ & $179.2 \pm 7^{\mathrm{c}}$ & $173 \pm 6.6^{\mathrm{e}}$ \\
\hline $400 \mathrm{mg} / \mathrm{L}$ & & & & & & \\
\hline
\end{tabular}

Mean values with different superscripts within the same groups are different significantly $(P<0.05)$

Table 10: Effects of three levels of clove powder with three temperatures levels on plasma cortisol level in common carp in anesthesia and recovery (Mean \pm SD).

\begin{tabular}{|c|c|c|c|c|c|c|}
\hline \multirow{3}{*}{$\begin{array}{l}\text { Group } \\
\text { Temp. }\end{array}$} & \multicolumn{6}{|c|}{ Cortisol level (nmol/L) } \\
\hline & \multicolumn{3}{|c|}{ Anesthesia } & \multicolumn{3}{|c|}{ Recovery } \\
\hline & Low & Normal & High & Low & Normal & High \\
\hline $200 \mathrm{mg} / \mathrm{L}$ & $477 \pm 6.2^{d}$ & $178 \pm 6.7^{\mathrm{g}}$ & $660 \pm 7.2^{c}$ & $1050 \pm 9.52^{\mathrm{f}}$ & $592 \pm 10.69^{\mathrm{h}}$ & $1577 \pm 6.34^{b}$ \\
\hline $300 \mathrm{mg} / \mathrm{L}$ & $103 \pm 10.6^{\mathrm{h}}$ & $422 \pm 2.8^{\mathrm{e}}$ & $191 \pm 5^{\mathrm{f}}$ & $1288 \pm 7.76^{\mathrm{c}}$ & $399 \pm 2.51^{\mathrm{i}}$ & $1595 \pm 6.27^{\mathrm{a}}$ \\
\hline $400 \mathrm{mg} / \mathrm{L}$ & $864 \pm 7.1^{\mathrm{a}}$ & $718 \pm 5.7^{\mathrm{b}}$ & $105 \pm 10^{\mathrm{h}}$ & $1101 \pm 9.08^{\mathrm{e}}$ & $961 \pm 10.45^{\mathrm{g}}$ & $1272 \pm 7.86^{\mathrm{d}}$ \\
\hline
\end{tabular}

Mean values with different superscripts within the same groups are different significantly $(P<0.05)$

Table 11: Effects of three levels of clove powder with three temperatures levels on plasma sugar level in common carp for anesthesia and recovery (Mean $\pm \mathrm{SD})$.

\begin{tabular}{|c|c|c|c|c|c|c|}
\hline \multirow{3}{*}{$\begin{array}{c}\text { Groups } \\
\text { Temp. }\end{array}$} & \multicolumn{5}{|c|}{ Anesthesia } & \multicolumn{3}{c|}{ Recovery } \\
\cline { 2 - 7 } & Low & Normal & High & Low & Normal & High \\
\hline $200 \mathrm{mg} / \mathrm{L}$ & $6.6 \pm 0.15^{\mathrm{c}}$ & $4.5 \pm 0.22^{\mathrm{e}}$ & $5.4 \pm 0.19^{\mathrm{d}}$ & $5.9 \pm 0.17^{\mathrm{d}}$ & $4.82 \pm 0.2^{\mathrm{e}}$ & $4.1 \pm 0.24^{\mathrm{f}}$ \\
\hline $300 \mathrm{mg} / \mathrm{L}$ & $2.9 \pm 0.34^{\mathrm{f}}$ & $7.4 \pm 0.14^{\mathrm{b}}$ & $7.9 \pm 0.13^{\mathrm{b}}$ & $3.7 \pm 0.27^{\mathrm{f}}$ & $5.9 \pm 0.17^{\mathrm{d}}$ & $10.3 \pm 0.1^{\mathrm{a}}$ \\
\hline $400 \mathrm{mg} / \mathrm{L}$ & $12.5 \pm 0.8^{\mathrm{a}}$ & $7.99 \pm 0.1^{\mathrm{b}}$ & $7.14 \pm 0.01^{\mathrm{b}}$ & $5.7 \pm 0.18^{\mathrm{d}}$ & $6.3 \pm 0.16^{\mathrm{c}}$ & $9.4 \pm 0.11^{\mathrm{b}}$ \\
\hline
\end{tabular}

Mean values with different superscripts within the same groups are different significantly $(P<0.05)$ 


\section{DISCUSSION}

\section{Anesthesia and recovery time}

Table (4) shows the anesthesia time associated with the effects of clove powder as an anesthetic at each concentration and water temperature. Significant relationships were found $(P<0.05)$ between water temperature, concentration and anesthesia time. The longest time of anesthesia in all stages (457.5, 490 and $540.66 \mathrm{sec}$.) respectively was show in $200 \mathrm{mg} / \mathrm{L}$ of cove powder with high temperature level, and the shortest time $(48.5,67$ and 154.66) was show in $400 \mathrm{mg} / \mathrm{L}$ of clove powder with high temperature level.

The environmental factors affect the efficacy of anesthetics in fish, it is not surprising that the relationship between clove powder dosage and water temperature was also significant $(P<0.05)$ regarding anesthesia and recovery time. As a poikilothermic animal; body temperature of fish closely follows their environments which result in temperature-related physicochemical passage of the drug into the fish (Coyle et al., 2004). Therefore, at lower water temperatures, higher doses or longer exposure times to anesthetic agents required due to the decrease in absorption rate (Ackerman et al., 2005). Walsh and Pease (2002) show that clove have an impact on the types of different fish in a wide range of temperatures and can be is absorbed and put well even in the low water temperature degree $\left(4{ }^{\circ} \mathrm{C}\right)$. In present study, as the concentration of clove powder increased the anesthetic time decreased, this inverse relation between anesthetic time and concentration required for anesthesia at each water temperature was also observed by Lemm (1993). Increased temperature has been reported to shorten induction and recovery times for a number of agents in several teleost species (Hoskonen and Pirhonen, 2004; Woolsey et al., 2004; Mylonas et al., 2005).

Rate of anesthesia is generally accepted as being temperature dependent. In general, induction time decreased as dose increased and recovery time increasing with raising temperature and doses. Detar and Mattingly (2004) also noted a similar temperature pattern for redbelly dace (Phoxinus erythrogaster). This trends also generally mimic those observed by Woolsey et al. (2004) for steelhead fry (O. mykiss) exposed to 25,50 , and $100 \mathrm{mg} / \mathrm{L}$ clove oil at 11,15 , and $20^{\circ} \mathrm{C}$. The same trend was observed in present study in which 200,300 and $400 \mathrm{mg} / \mathrm{L}$ of clove powder used with low $\left(9 \pm 1^{\circ} \mathrm{C}\right)$, normal $\left(27 \pm 1^{\circ} \mathrm{C}\right)$ and high temperature $\left(33 \pm 1^{\circ} \mathrm{C}\right)$. However, higher anesthetics concentration has more efficacies with increasing in water temperature as proved by Detar and Mattingly (2004). While in present results in the lower anesthetics (200 and $300 \mathrm{mg} / \mathrm{L}$ ) dosages with lower temperature degree, the anesthesia time was shorter, this is may be due to low temperature is also have a sedation effect on fish as reported by Hovda and Linley (2000).

Optimum anesthetic concentrations are usually expected to induce anesthesia within $3 \mathrm{~min}$ and recover within10 minute. When considering the water temperature, all anesthesia experiment results satisfy the above condition. Thus, it is decided optimum anesthesia concentration that is shown as anesthesia time within $3 \mathrm{~min}$ and fast recovery by water temperature. The optimal anesthesia concentrations for common carp were $300 \mathrm{mg} / \mathrm{L}$ at low, normal and high temperature level, the difference between anesthesia time after this dose generally was insignificant $(P<0.05)$.The recovery time that show in Table (5). The interaction of water temperature and dose on recovery time was also significant $(P<0.05)$. Generally as the concentration of the anesthetic and water temperature increased, recovery time significantly $(P<0.05)$ increased.

The results of the recovery time were more consistent, fish treated at the highest concentration recovering later than fish treated at the lowest concentration (Gullian and Villanuera, 2009). One of the criteria set by Guilderhus and Marking (1987) for the efficacy of an anesthetic was that recovery should take no longer than 10 minute. Using clove powder, this criterion was met at all concentrations and temperatures. Induction and recovery times varied in relation to water temperature (Zahl et al., 2009). Terzioglu (2001) reported that the effects of temperature on induction and recovery times of 2phenoxyethanol were insignificant in sea bream.

The temperature related to an anesthetic could be explained by the dependence of metabolic rate on temperature, the faster induction and recovery times at higher water temperatures may be related to an increased oxygen demand due to increased basal metabolism and lower oxygen solubility, leading to enhanced respiration and blood flow, and thus accelerated physiologic processes involving absorption and terminating the anesthesia (Gomes et al., 2011).

Rainbow trout exposed for $10 \mathrm{~min}$ to AQUI-S show higher Isoeugenol levels in fillets obtained at higher temperatures, and silver perch (Bidyanus bidyanus), exposed to $50 \mathrm{mg} / \mathrm{L}$ of clove oil also presented higher eugenol levels in fillets obtained at higher temperatures, in addition, silver perch were also able to clear their flesh of eugenol more rapidly at higher temperatures (Kildea et al., 2004), which would help to explain the shorter recovery times of silver catfish acclimated to higher temperatures. While in present results all three concentrations were generally show lower recovery time with normal temperature and it is agree with results of Bagheri and Imanpour 


\section{Nasreen M. Abdulrahman, et al.}

(2011) in that level of temperature except in stage III of recovery.

In general, higher water temperatures appear to augment both the anesthetic effect and the recovery time of the fish in higher concentration (Prince and Powell, 2000; Walsh and Pease, 2002; Hoskonen and Pirhonen, 2004). This is probably related to the higher metabolism and opercular ventilation rates of fish maintained at higher temperatures (Constantinos et al., 2005).

\section{Ventilation rates}

The ventilation rate at the different stages of anesthesia in $C$. carpio is presented in Table (6). The ventilation rate was significantly $(P<0.05)$ affected by temperature and clove powder concentration. In stage I when water temperature and the concentration of clove powder increased, the ventilation rate also increased. While in stage II and stage III all three concentration of clove powder with normal temperature degree show lower ventilation rate compared to other groups. In the stage I of the anesthesia, ventilation rate was more than other two stages and this is may be due to effect of a new environment as well as effect of handling (Pandit and Ghosh, 2005).

Higher water temperatures is related to the higher ventilation rates of fish maintained at higher temperatures (Constantinos et al., 2005) because in high temperature fish is more active and had high metabolic rate therefore in higher temperature the ventilation rates are more than lower temperature (Allen, 2009) which is agree with present result.The ventilation rate at the different stages of recovery in common carp is presented in Table (7). The ventilation rate was significantly $(P<0.05)$ affected by temperature and clove powder concentration and in stage I, II and III all three concentrations of clove powder with normal temperature degree show lower ventilation rate compared to other groups.

The solubility of oxygen decreases as the water temperature rises and may lead to an additional need for enhanced respiration and blood flow. It has been shown that the metabolic rate and oxygen consumption of Atlantic cod double between 5 and 15 ${ }^{\circ} \mathrm{C}$ (Schurmann and Steffensen, 1997). A significantly higher frequency of respiration (opercular beats) at high water temperatures has been found both in gilthead sea bream and European sea bass (Mylonas et al., 2005). Moreover, fishes are ectotherms (coldblooded), which means that warm temperatures can raise their metabolism and consequently their breathing rate also (Reebs, 2009).

\section{Hematological parameters}

Table (8) show the effects of three levels of clove powder with three temperatures levels on red blood cells level in common carp for anesthesia and recovery. The results of the present study showed the lowest level of RBC [0.84( $10^{12}$ cells/L)] with lower concentration $(200 \mathrm{mg} / \mathrm{L})$ of clove powder in normal temperature degree. While the highest level of $\mathrm{RBC}$ $\left[1.45\left(10^{12}\right.\right.$ cells/L)] was show in $300 \mathrm{mg} / \mathrm{L}$ of clove powder with low temperature degree. For the recovery the lowest and highest RBC level $[0.84$ and $1.38\left(10^{12}\right.$ cells/L)] was found in $400 \mathrm{mg} / \mathrm{L}$ of clove powder with normal and high temperature degree, respectively.

The blood is fluid connective tissue which acts as the main transporting system of the body in all animals. In poikilotherms like fish it plays vital role during every movement for maintaining the physiological nature of the body with respect to the fluctuating environmental parameters (Yeragi and Lendhe, 2004). The fish living in the temperature fluctuations faces the problem of oxygen affinity; so as to compensate for the effect of temperature. This seems even more likely when the ability of many fishes to undergo thermal metabolic acclimation is considered (Jagtap et al., 2013). Increased in number of RBC can be due to acute stress and spleen evacuation (Gomulka et al., 2008).

Table (9) show the effects of three levels of clove powder with three temperatures levels on white blood cells level in common carp for anesthesia and recovery. According to present results in anesthesia, $200 \mathrm{mg} / \mathrm{L}$ of clove powder with high temperature degree show the lowest level of WBC $\left[165.2\left(10^{9}\right.\right.$ cells/L)]. While the highest level of WBC [199.4(109 cells/L)] was show in $300 \mathrm{mg} / \mathrm{L}$ of clove powder with low temperature degree. For the recovery the lowest and highest WBC level [149.1 and 200.3 $\left(10^{9}\right.$ cells/L)] were found in $300 \mathrm{mg} / \mathrm{L}$ of clove powder with low and normal temperature degree, respectively.

The immune system and response of fish can be greatly influenced by various external factors like temperature, light, water quality, salinity and different stress inducers (Magnadottir, 2010). Decreases in temperature, which are important due to the poikilothermic nature of fish, affect the rate of their physiological functions (Hayward et al., 2009). Farrell (2011) reported that high levels of the adrenocorticotrophic hormone and cortisol, typically found in blood during stress, they are known to reduce lymphocyte numbers, leading to a low WBC count (leukopenia). This agrees with present results that show in 8 and 9, in which the WBC level is decreased with increasing cortisol level. 


\section{Plasma cortisol}

The cortisol level in plasma is presented in Table (10). Both water temperature and clove powder concentration had a significant effect on plasma cortisol. In the anesthesia the lowest cortisol level $(103 \mathrm{nmol} / \mathrm{L})$ was found in the low temperature degree with $300 \mathrm{mg} / \mathrm{L}$ of clove powder. While the highest cortisol level $(864 \mathrm{nmol} / \mathrm{L})$ was found in the low temperature degree with $400 \mathrm{mg} / \mathrm{L}$ of clove powder. In recovery the lowest and highest cortisol level (399 nmol/L and $1595 \mathrm{nmol} / \mathrm{L}$ ) was found in $300 \mathrm{mg} / \mathrm{L}$ of clove powder with normal and high temperature degree, respectively. Such different results seem to be caused by different stresses imposed on fish (Park et al., 2008).

Rapid changes in water temperature may cause stress to fish and affect their metabolic rate, circulation, uptake of the anesthetic agent and can cause increase in cortisol level (Zahl et al., 2009), it is agree with present results. Several factors may affect the cortisol response to anesthetics, including the method of administration, chemical properties of the agents, the mode of action, effects and adverse effects, induction time and the dosage used. Since cortisol is released over the gills, factors influencing gill blood flow, respiration rate and diffusion area will also influence cortisol release (Zahl, 2011).

\section{Plasma sugar}

The sugar level in plasma is presented in Table (11). In the anesthesia the lowest and highest sugar levels (2.9 $\mathrm{mmol} / \mathrm{L}$ and $12.5 \mathrm{mmol} / \mathrm{L}$ ) were found in low temperature degree with 300 and $400 \mathrm{mg} / \mathrm{L}$ of clove powder, respectively. In recovery the lowest sugar level (3.7 $\mathrm{mmol} / \mathrm{L}$ ) was found in $300 \mathrm{mg} / \mathrm{L}$ of clove powder with low temperature degree. The highest sugar level $(10.3 \mathrm{mmol} / \mathrm{L})$ was found in $300 \mathrm{mg} / \mathrm{L}$ of clove powder with high temperature degree. Generally water temperature has effect on plasma sugar as reported by Shi et al. (2006). Plasma sugar is recognized as useful indicators of stress in fish, among study that use other fish anesthetic. No increases in plasma sugar levels were reported in red drum (Sciaenops ocellatus) simultaneously exposed to MS- 222 and Quinaldine anesthetic (Park et al., 2008). Strong acute stress is usually followed by increased of sugar level. sugar concentrations between $2-9 \mathrm{mmol} / \mathrm{L}$ were reported for the species by Lappivara (2001); Brzuzan et al. (2009); Siikavuopio et al. (2010).

\section{REFERENCES}

ABU-ELHINI, J., ABD-ELKARIM, A., LUAY, M. AND SULAIMAN, M.D. 2013. Impact of incentive starvation on the growth of common carp (Cyprinus carpio L.). Journal of Basra Agricultural Sciences, 26: 188-182.

ACKERMAN, P.A., MORGAN, J.D. AND IWAMA, J.K. 2005. Anesthetics. Appendix to CCAC guidelines on: the care and use of fish in research, teaching and testing.
Canadian Council on Animal Care: Ottawa CA. (Available electronically

Fish/Fish2520Anesthetics).

AKINROTIMI, O.A., GABRIEL, U.U. AND OROKOTAN, O.O. 2013. Changes in enzymes activities of Clarias Gariepinus brood fish exposed to anaesthetics metomidate. Applied Ecology and Environmental Sciences, 1(3): 37-40.

AL-JASHAMI, K.J., AL-BIATY, M.N., AL-OBAEDY, H.J. AND AL-JEBURY, A.G. 2002. New anesthetic for common carp (Cyprinus carpio L.) fish. Iraqi Journal Agriculture, 7(1): 111-116. (In Arabic)

ALLEN, B. 2009. The effect of water temperature on goldfish respiration rate. Cited by Wikipedia Online Encyclopedia.

BAGHERI, T. AND IMANPOUR, M.R. 2011. The efficacy, physiological responses and hematology of Persian Sturgeon (Acipenser persicus) to clove oil as an anesthetic agent. Turkish Journal of Fisheries and Aquatic Sciences, 11: 477- 483.

BROWN, L.A. (2011). Anaesthesia for fish. Viet. fish, 8 (2): 68-70.

BRZUZAN, P., WOŹNY, M., CIESIELSKI, S., ŁUCZYŃSKI, M.K., GÓRA, M., KUŹMIŃSKI, H. AND DOBOSZ, S. 2009. Microcystin-LR induced apoptosis and mRNA expression of p53 and cdkn1a in liver of whitefish (Coregonus lavaretus L.). Toxicon, 54: 170-183.

CONSTANTINOS, C.M., CARDINALETTI, G., SIGELAKI, I. AND POLZONETTI-MAGNI, A. 2005. Comparative efficacy of clove oil and 2phenoxyethanol as anesthetics in the aquaculture of European sea bass (Dicentrarchus labrax) and gilthead dea bream (Sparus aurata) at different temperatures. Aquacalture, 246:467-481

COYLE, S.D., DURBOROW, R.M. AND TIDWELL, J.H. 2004. Anesthetics in aquaculture. Southern Regional Aquaculture Center Publication No. 3900.

DETAR, J.E. AND MATTINGLY, H.T.2004. Response of Southern Redbelly Dace to clove oil and MS-222: effects of anesthetic concentration and water temperature. Fish and Wildl Agencies, 58:219-227.

FARRELL, A.P. 2011. Encyclopedia of fish physiology: from genome to environment. Vancouver, BC, Canada British Library Cataloguing in Publication Data, N.: 2011923567, PG. 991.

GHOLIPOURKANANI, H., MIRZARGAR, S.S., SOLTANI, M., AHMADI, M., Abrishamifar, A., Bahonar, A. and YOUSEFI, P. 2011. Anesthetic effect of tricaine methanesulfonate, clove oil and electroanesthesia on lysozyme activity of Oncorhynchus mykiss. Iranian Journal of Fisheries Sciences, 10(3): 393-402.

GOMES, D.P., CHAVES, B.W., BECKER, A.G. AND BALDISSEROTTO, B. 2011. Water parameters affect anaesthesia induced by eugenol in silver catfish (Rhamdia quelen). Aquaculture Research, 42(6): 878886.

GOMULKA，P., ZARSKI，D., KUCHARCZYK, D., KUPREN, K., KREJSZEFF, S. AND TARGONSKA, K. 2008. Acute ammonia toxicity during early ontogeny of chub (Leuciscus cephalus Cyprinidae). Aquatic Living Recourse, 24: 211-217. 
GUILDERHUS, A. and Marking, L.L. 1987. Comparative efficacy of 17 anaesthetic chemicals on rainbow trout. North American Journal of Fisheries Management, 7(4): 288-292.

Gullian, M. and Villanueva, J. 2009. Efficacy of tricaine methanesulphonate and clove oil as anaesthetics for juvenile cobia (Rachycentron canadum). Aquaculture Research, 40(7): 852-860.

HAYWARD, C.J., BOTT, N.J. AND NOWAK, B.F. 2009. Seasonal epizootics of sea lice, Caligus spp., on southern bluefin tuna, (Thunnus maccoyii Castelnau), in a long-term farming trial. Journal of Fish Disease, 32: 101-106.

HOLLOWAY, A.C., KEENE, J.L., NOAKES, D.G. AND MOCCIA, R.D. 2004. Effects of clove oil and MS-222 on blood hormone profiles in rainbow trout (Oncorhynchus mykiss Walbaum). Aquaculture Research, 35(11): 10251030.

HOSKONEN, P. AND PRIHONEN, J. 2004. Temperature effects on anaesthesia with clove oil in six temperate-zone fishes. Journal Fish Biology, 64(2): 1136-1137.

HOVDA, J. AND LINLEY, T.J. 2000. The potential application of hypothermia for anesthesia in adult Pacific salmon. North American Journal Aquaculture, 62: 67-72.

IWAMA, G.K., MCGEER, J.C. AND PAWLUK, M.P. 1989. The effects of five fish anaesthetics onacid-base balance, hematocrit, cortisol and adrenaline in rainbow trout. Canadian Journal of Zoology, 67:2065-2073.

JAGTAP, A.R., MALI, R.P, BARDE, R.D.2013. Thermoacclimatory variation in the red blood cell indices of freshwater fish, Channa punctatus Godavari river, Nanded. International Journal of Life Sciences, 1(1): 1721.

KAKOOLAKI, S., SHARIFPOUR, I., SOLTANI, M., EBRAHIMZADEH MOUSAVI, H.A., MIRZARGAR, S. AND ROSTAMI, M. 2010. Selected morpho-chemical features of hemocytes in farmed shrimp, (Fenneropenaeus indicus) in Iran . Iranian Journal of Fisheries Sciences, 9(2), 219-232.

KAPS, M. AND LAMBERSON, W. R. 2004. Biostatistics for animal science. CABI Publishin: 459pp.

KILDEA, M.A., ALLAN, G.L. AND KEARNEY, R.E. 2004. Accumulation and clearance of the anaesthetics clove oil and AQUI-S ${ }^{\mathrm{TM}}$ from the edible tissue of silver perch (Bidyanus bidyanus). Aquaculture, 232(1-4), 265-277.

LAPPIVARA, J. 2001. Effects of acute handling stress on whitefish Coregonus lavaretus after prolonged exposure to biologically treated and untreated bleached kraft mill effluent. Arch Environment Contamination Toxicology, 41: 55-64.

LEMM, C.A. 1993. Evaluation of five anesthetics on striped bass. U.S.'Department of the Interior Fish and Wildlife Service, Resource Publication 196 Washington, D.C.

MAGNADOTTIR, B. 2010. Immunological control of fish diseases. Journal of Marine Biotechnology, 12: 361-379.

MARKING, L.L. AND MEYER, F.P. 1985. Are better anaesthetics needed in fisheries?. Fisheries, 10(2): 2-5.

MYLONAS, C.C., CARDINALETTI, G., IGELAKI, I. AND POLZONETTI, M. 2005. Comparative efficacy of clove oil and 2-phenoxyethanol as anaesthetics in the aquaculture of European sea bass (Dicentrarchus labrax) and gilthead sea bream (Sparus aurata) at different temperatures. Aquaculture Research, 246(4): 467-481.
PARK, M.O., HUR, W.J., IM, S.Y., SEOL, D.W., LEE, J. AND PARK, I.S. 2008. Anaesthetic efficacy and physiological responses to clove oil-anaesthetized kelp grouper (Epinephelus bruneus). Aquaculture Research, 39(8): 877-884.

PANDIT, D.N. AND GHOSH, T.K. 2005. Effect of Benzocaine on opercular movement and oxygen consumption in (Channa punctatus) Bloch. Journal of the Indian Fisheries Association, 32: 149-155.

PRINCE, A. AND POWELL, C.2000. Clove oil as an anesthetic for invasive field procedures on adult rainbow trout. North American. Journal Fish. Management, 20: 1029-1032.

REEBS, S.G. 2009. Oxygen and fish behaviour. Howfishbehave, Phd Review, Université de Moncton, Canada.Availablefrom: <http://www.howfishbehave.ca/pdf/oxygen.pdf.

ROSS, L.G. AND ROSS, B. 2008. Anaesthetic and sedative techniques for aquatic animals. $3^{\text {rd }}$ Edition. Blackwell publishing: 228pp.

SCHURMANN, H. AND STEFFENSEN, J.F.1997. Effects of temperature, hypoxia and activity on the metabolism of juvenile Atlantic cod. Journal Fish Biology, 50: 1166 -1180 .

SHI, X., LI, D., ZHUANG, P., NIE, F. AND LONG, L. 2006. Comparative blood biochemistry of Amur sturgeon (Acipenser schrenckii) and Chinese sturgeon (Acipenser sinensis). Fish Physiology Biochemist, 32(3): 63-66.

SIIKAVUOPIO, S.I., KNUDSEN, R. AND AMUNDSEN, P.A. 2010. Growth and mortality of Arctic charr and European whitefish reared at low temperatures. Hydrobiologia, 650: 255-263.

TERZIOĞLU, E. 2001. The anesthetic effects of 2Phenoxyethanol on Seabream (Sparus aurata, L.,) at different concentrations and temperatures. Master Thesis. Ege University Fisheries Faculty, Bornova, Đzmir: 112pp.

TRUSHENSKI, J. T., BOWKER, J. D., COOKE, S. J., ERDAHL, D., BELL, T., MACMILLAN, J. R., YANONG, R. P., HILL, J. E., FABRIZIO, M. C., GARVEY, J. E. AND SHARON, S. 2013. Issues regarding the use of sedatives in fisheries and the need for immediate-release options. Transactions of the American Fisheries Society, 142(2): 156-170.

VELÍŠEK，J.，SVOBODOVÁ，Z., PIAČKOVÁ，V., GROCH, L. AND NEPEJCHALOVA, L. 2005. Effects of clove oil anaesthesia on common carp (Cyprinus carpio L.). Veterinarni Medicina, 50(6): 269-275.

WAGNER, G.N., SINGER, T.D. AND MCKINLEY, R.S. 2003. The ability of clove oil and MS-222 to minimize handling stress in rainbow trout (Oncorhynchus mykiss Walbaum). Aquaculture Research, 34(13): 1139-1146.

WALSH, C.T. AND PEASE, B.C. 2002. The use of clove oil as an anaesthetics for the longfinned ell, (Anguilla reinhardtii Steindachner). Aquaculture Research, 33(8): 627-635.

WOOLSEY, J., HOLCOMB, M. AND INGERMANN, R.L. 2004. Effect of temperature on clove oil anesthesia in steelhead fry. North American Journal Aquaculture, 66: 35-41. 
YERAGI, S.G. AND LENDHE, R.S. 2004. Seasonal variations in the hematological parameters of Catla catla and Tilapia mossambica of Phirange Kharbav Lake. Dist. Thane, Journal of Comparative Toxicology Physiology, 1 (3-4): 265-266.

ZAHL, I. H. 2011. Anaesthesia of farmed fish with special emphasis on Atlantic cod (Gadus morhua) and Atlantic halibut (Hippoglossus hippoglossus). In School of Veterinary Science, Doctor of Philosophy, The University OF BERGEN: 213 PP.

ZAHL, I.H., KIESSLING, A., SAMUELSEN, O.B. AND HANSEN, M.K. 2009. Anaesthesia of Atlantic cod (Gadus morhua) - effect of pre-anaesthetic sedation, and importance of body weight, temperature and stress. Aquaculture, 295(1-2): 52-59.
How to cite this article:

Nasreen M. Abdulrahman, Bakhan R. Hassan and Nadir A. Salman, 2018. Physiological Impacts Of Using Clove Powder As Fish Anesthetic On Young Common Carp (Cyprinus Carpio L.) Under Different Levels Of Temperatures. Journal of Applied Veterinary Sciences, 3 (1): $1-11$.

DOI: https://dx.doi.org/10.21608/javs.2018.62720 